\title{
Farmers' Woodlots Management and Sustainable Livelihood Development: A Case Study in Southern Sri Lanka
}

\author{
Mangala De Zoysa ${ }^{1, *}$, Makoto Inoue $^{2}$ \\ ${ }^{1}$ Department of Agricultural Economics, Faculty of Agriculture, University of Ruhuna, Sri Lanka \\ ${ }^{2}$ Global Forest Environmental Studies, Graduate School of Agricultural and Life Sciences, The University of Tokyo, Japan
}

Copyright $\bigcirc 2016$ by authors, all rights reserved. Authors agree that this article remains permanently open access under the terms of the Creative Commons Attribution License 4.0 International License

\begin{abstract}
A study was conducted on how a community forestry program improved livelihood development opportunities while addressing sustainable forest resource management. Data were collected through key informant survey, field survey, group discussions and field observation and analyzed to examine the contribution of a program in Nidahas Gama Sri Lanka using the livelihood framework method. The program improved human capital through skills development and training. The natural capital of the program was improved through development of farmers' woodlots (FWLs), home gardens and other agricultural land. Household welfare development, widening of the sources of energy for cooking and improvement of infrastructure were identified as main physical capital development of the program. The program increased household annual income, promoted household ability in self-financing forest and agricultural activities, and improved capabilities in formal banking transactions, under financial capital development. The main strategies used for developing social capital are: formation of groups and networks; trust and solidarity development; development of social cohesion, inclusion and empowerment; and information and communication improvement. Overall, the program has been highly successful in meeting the various livelihood development components.
\end{abstract}

Keywords Farmers Woodlots, Home-gardens, Household Welfare, Skill Development, Self-financing, Social Networks and Solidarity

\section{Introduction}

Participatory Forestry Management Project (PFMP) activities in Sri Lanka have attracted international interest and a large amount of donor funding. Programs where local communities participate in managing forests have evolved as a means of resolving environmental problems while satisfying the subsistence needs of rural communities [1]. Participatory Forestry Management (PFM) became institutionalized in Sri Lanka during the 1980s following a global trend, and forest sector administrative reforms were implemented that gave greater roles to communities in forest management [2]. The PFM approach has become popular due to the poverty of the rural people and the scarcity of their livelihood opportunities. Many of the forestry initiatives of Sri Lanka, after introduction of the National Forest Policy in 1980, called for a PFM approach [3]. The National Forest Policy in Sri Lanka was amended in 1995 to provide the necessary policy and legal frameworks for communities to participate in forest resource development. The Forest Department had established about 15,500 ha of Farmers' Woodlots (FWL) in 19 districts of Sri Lanka under the Participatory Forestry Management Project (PFMP) implemented during 1993 to 1999. Many other FWL development programs were initiated in Sri Lanka in 2002, in which small blocks of state land were given on a 25 -year lease to local communities to plant both forest trees and cash crops. The main concerns of Participatory Forestry Management Project are to make forestry management more efficient and to involve communities through the devolution of management functions and contributions to the local livelihoods. FWL development program is not only a mechanism of handing over forests to local people but also to safeguard their livelihoods and address the forest sector governance and sustainable forest resource management. However, the common criticism for FWL development programs is that there is a lack of evidences showing clear and consistent contributions of FWLs to local livelihoods other than general improvements of the physical condition.

The sustainable livelihoods framework (SLF) which emphasised the economic attributes of livelihoods as mediated by social-institutional processes, is gaining popularity [4]. The Sustainable Livelihoods Framework is people-centred, and provides users with a more accessible 
means of understanding and analyzing policies, institutions and processes [5]. It provides a realistic framework for assessing the direct and indirect effects on people's living conditions. Application of the framework requires consideration of five types of assets: natural capital, physical capital, financial capital, human capital and social capital. Households engage in livelihood activities on the basis of: assets available; opportunities arising; resource access; risk aversion and perceived benefits [6]. Under the sustainable livelihoods approach (SLA), community forestry programs have been specifically formulated to improve local livelihoods and abate environmental degradation through the empowerment of local community-based user groups to manage their forest resources [7]. People have converted natural capital into 'cultivated capital' that includes a wide range of permanent systems such as agriculture and forestry to maximize the production of some functions and services [8]. The natural capital stock of human-cultivated ecosystems such as forests and crops influence the three dimensions: ecological, social and economic 'functions of natural capital' of sustainable development [9]. Livelihood approaches that promote community-centred development are responsive and participatory; they and favour multidisciplinary and multilevel development interactions. The SLF allows people to cope with and recover from stresses and shocks of natural resources, infrastructure, and economic cultural and political environment. Further, the SLF maintain or enhance their capabilities and assets of natural, physical, financial, social and human capital both now and in the future, while not undermining the natural resource base [10]. Under the SLA, school enrolment is used to measure useful human capital in terms of labour productivity. General education is considered community input that relate to the entrepreneurial outputs in the form of livelihood opportunity identification and pursuit [11]. Further, social capital is an important potential by-product of education [12]. Skills and knowledge in communities can be more easily enhanced if the training program on livelihood development creates socially acceptable and economically viable community forestry whereby the attitudes of all stakeholders are changed [13]. Community forestry is expected to have a positive impact on household welfare, and the welfare benefits have to be distributed evenly among the beneficiaries [14]. Community forestry beneficiaries are able to generate new employment within their villages and use profits to invest in other enterprises and build community assets and physical assets without assistance from the government [15]. The establishment of credit, including through micro-credit schemes, provide "financial capital" for households under participatory forestry programs [16]. Social capital, where communities manage natural resources, is developed through collective action of communities with relations of trust, reciprocity, common rules, norms, and connectedness in institutions [17]. Consensus building is a form of negotiation that builds the capacity of people to develop a dialogue with each other to generate mutual gains for all parties with the minimum of compromise and trade-off over the allocation of scarce 'environmental' resources [18]. Usually, power disparities and households' interests are better represented when communities are involved in making important management decisions about their forest resource use and development, and related financial matters [19]. Social networks have value as interaction and connections foster cooperation to achieve common ends is the core idea of social capital [20].

\section{The Study Area}

The Hambantota district was selected from districts where the FWL program was implemented in 2002 because it is nearest to the Matara district where the University of Ruhuna is located. After the consultation of the Additional Conservator General of Forest, Forest Department of Sri Lanka as well as the District Forest Officer in Hambantota District through a key informant survey, the FWL development program implemented in Nidahas Gama situated in Ranna Forest Range area was selected for the study. The farmers' woodlot development program of Nidahas Gama was selected for the study (Map 1). Under the PFMP in 2002, the District Office of the Forest Department in Hambantota District initiated a teak-based FWL development program to rehabilitate the degraded government forest land available in Nidahas Gama, in Ranna forest range area. Nidahas Gama is located $4 \mathrm{~km}$ turning from Ranna on the Galle-Hambantota main road, 4 hours drive from the capital city Colombo. 


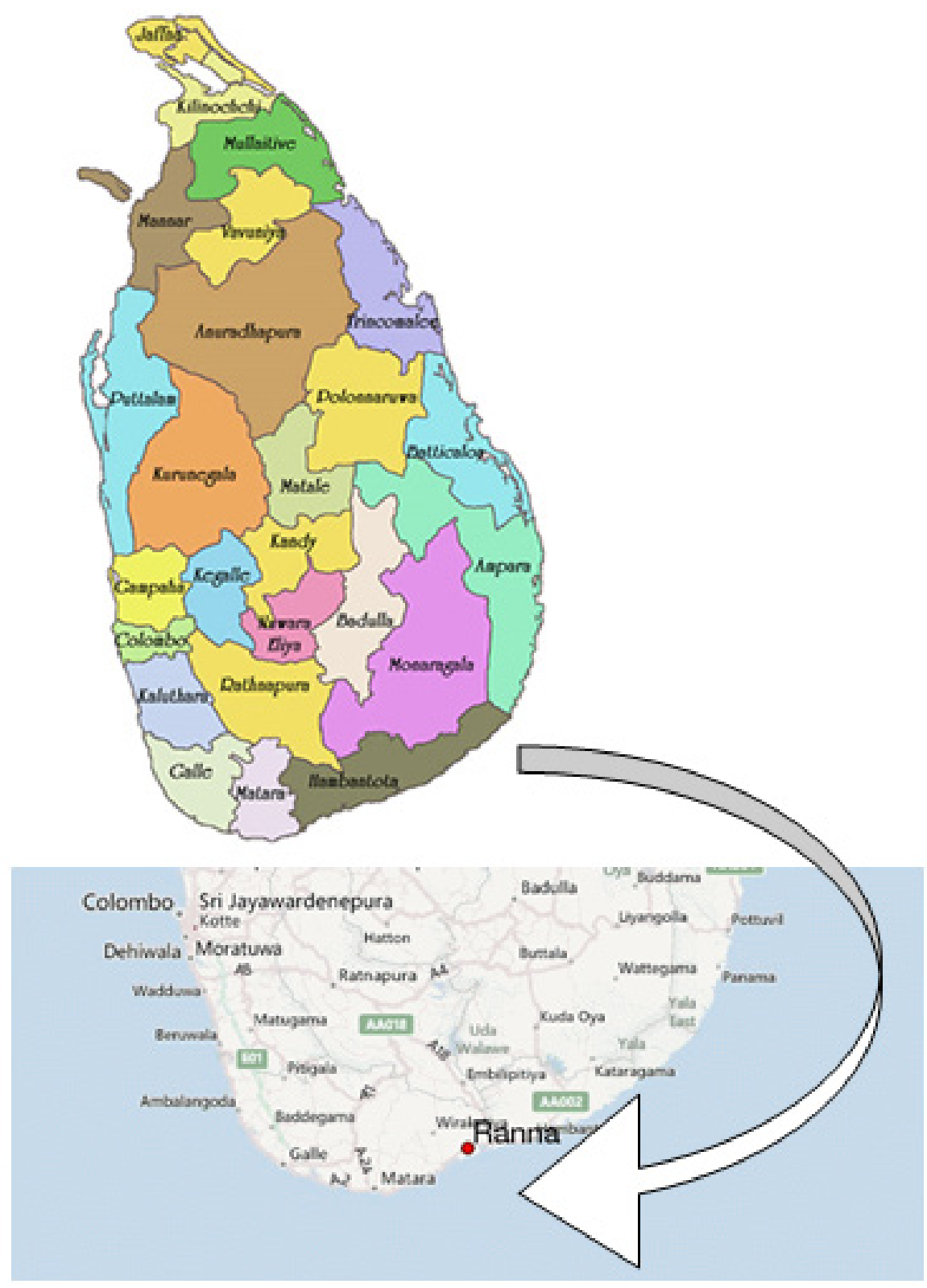

Figure 1. Ranna Forest Rage in Hambantota

The FWL development program distributed 19.5 ha of degraded forest land among 39 beneficiaries, allocating 0.5 ha for each. The program aims at managing trees not as single isolated entities, but as part of overall community forestry strategy as well as rural development strategy. After more than 10 years of implementation of FWL development program in Nidahas Gama, it is important to analyze the contribution of FWL development program in livelihood development of participants in order to assess the success of the program. More than $25 \%$ of the world's population (close to 1.6 billion people) rely on forest resources for their livelihoods [21]. Only very few studies has been conducted in the world to investigate the changes of land-use from shifting cultivation to commercialized forest plantation, allocating forest tenure rights to shifting cultivators and rural poor. Hence, the remarkable experiences of the FWL development program implemented at Nidahas Gama in Sri Lanka could be used as an important literature and guidance for the promotion of FWL development programs locally and internationally. The study will facilitate understanding policies, institutions and processes of farmer woodlot program, and assessing the direct and indirect effects on people's living conditions in five types of assets: natural capital, physical capital, financial capital, human capital and social capital.

\section{Methodology}

The research was conducted collecting primary data through key informant survey, field study, discussions and observations as well as collecting secondary data from 
related institutions. The collected data were analyzed and interpreted the contribution of the FWL development program in Nidahas Gama on livelihood development in terms of human capital, natural capital, physical capital, financial capital, social capital, and governance.

\section{Main Variables}

This study therefore analyzes the contribution of the FWL development program in Nidahas Gama on livelihood development of the beneficiaries in terms of human capital, natural capital, physical capital, financial capital, and social capital development. The term 'capital' in this paper is used for the "stock" and "systems" of the FWL development program that has the capacity to provide a flow of goods and services particularly to the program beneficiaries. The improvement of human capital through the FWL development program is analysed in terms of skills development and training. The development of natural capital by the program is analysed as development of farmers' woodlots (FWLs), home gardens and other agricultural lands. The physical capital development of the program is analysed based on household welfare development, widening of the sources of energy for cooking and improvement of infrastructure. The financial capital development of the program is analysed through increased household annual income, promoted household ability in self-financing forest and agricultural activities, and improved capabilities in formal banking transactions,. The development of social capital is analysed in terms of formation of groups and networks; trust and solidarity development; development of social cohesion, inclusion and empowerment; and information and communication improvement.

\section{Data Collection}

\section{Key Informant Survey}

The relevant background information was collected from the District Forest Officer, Range Forest Officer and Forest Extension Officers of the district through personal interviews. Researchers conducted the interviews and discussions at the District Forest Office. The information concerning initiation of the program, development of program activities and implementation of the program as well as the procedure followed in selecting beneficiaries of the program were collected through the interviews and discussions.

\section{Collection of Primary Data}

A field survey was conducted by the researchers interviewing the beneficiaries of the program to collect information concerning the contribution of FWLs as well as other rural development components of the FWL development program implemented in Nidahas Gama for the livelihood development of the beneficiaries. A literature survey was conducted to collect information on theories, concepts and past research finding concerning livelihood development and community forestry. Based on the information collected through the literature survey and key informant survey, a structured questionnaire was prepared. The questionnaire was pre-tested observing the study area and communicate with 4 beneficiaries meeting at Nidahasgama. It was intended to select 30 beneficiaries randomly from the total 39 beneficiaries of the FWL development program for the field survey. From the total of 39 beneficiaries of the program, 30 provided information during the field survey conducted by the researchers during 6 days visiting Nidahasgama. The researchers conducted personal interviews administering the questionnaire pretested and then corrected according to the existing conditions of the study area. The questionnaire contained groups of questions covering main aspects of the development of human capital, natural capital, physical capital, financial capital, and social capital under implementation of the FWL development program. Further, the focus group discussions with beneficiaries and elderly people of the village facilitated collection of additional information which assisted interpretation of some of the data collected through the field survey. The discussants were able express their views and make their comments freely, based on their knowledge, experiences particularly the qualities, and perceptions concerning the FWL development program and it's activities, as a community group rather than individual beneficiaries. The field observations provided more information as well as clarifications and confirmation of the information collected as secondary data, in key informant survey and focal group discussions and questionnaire survey. Further, the field observation facilitated to understand tangible impacts of the program in the village.

\section{Collection of Secondary Data}

Important secondary data were also collected from the documents available in District Forest Office in Hambantota in order to identify important characteristics of selected beneficiaries and understand about main implemented activities under the FWL program. In addition to the FWL activities, information was collected about other activities including the home garden development component and the small industries component implemented under FWL development program during the above interviews, discussions and documents. The Forest Department had coordinated other rural development components under the FWL development program, through the Department of Agriculture, Department of Small Industries, NGO, and Rural Development Banks.

\section{Results and Discussion}

\section{Human Capital Development of the FWL Development Program}

Before the FWL development program, livelihood was depended on economic and subsistence activities that usually include harvesting forest products, shifting cultivation and fishing. All the farmers participating in the FWL 
development program are mature farmers with an average age of 59 years, and ranging from 40 years to 74 years. These beneficiaries of the program are literate $(100 \%)$, and able to take specialized technical training for forest management activities. Almost all the beneficiaries (93\%) are educated beyond the primary level of education. The majority $(73 \%)$ have secondary level of education, and $20 \%$ passed their GCE $(\mathrm{O} / \mathrm{L})$ examination. Education generates significant positive externalities including building social capital in a society. These beneficiaries are proud of the higher level of education (beyond the secondary level) they can now provide for the younger generation (100\%) of their average 5 member families (maximum 8 and minimum 2). They are studying mainly at the popular Ranna National School which is located $3 \mathrm{~km}$ from Nidahasgama, managed by the government under free education system. The education process produces more informed young generation and eventually, the program seems to have beneficiaries capable of promoting social interaction, networking, and social responsibility, that starts in schools.

Skills Development of the FWL Development Program Beneficiaries: All the beneficiaries selected for the FWL development program are former traditional farmers who used shifting cultivation to grow indigenous vegetables and field crops. Presently all the beneficiaries of the FWL development program $(100 \%)$ posses sufficient scientific knowledge and practical skills in establishment and sustainable management of their woodlots, as well as management of trees in non-forest lands such as home gardens and agricultural lands. Therefore, the establishment and management of Teak woodlots promoted by the program required relatively little human capital.

The educated families and skilled beneficiaries facilitated the movement of their labour across economic activities. They have together with Forest Department assisted in sectoral restructuring as new industrial activities developed as part of the process of FWL development program. Since the Nidahas Gama is located very close to the sea (Indian Ocean), the majority of the villagers have been fishermen for many generations. The beneficiaries find enough spare time for fishing after efficient allocation of their time for FWL deployment program. From the FWL development program beneficiaries, $67 \%$ are actively involving in fishing industry as one of their main sources of income. Some of the beneficiaries $(27 \%)$ posses other skills such as fibre product manufacturing, construction work, plumbing, wood carving, clay bricks making, management of small business ventures etc., for earning additional household income, after participation in the program.

Training for the FWL Development Program Beneficiaries: The Divisional Forest Officer and his Extension Officers trained all the FWL development program beneficiaries soon after they were selected in 2002 . They were trained on establishment and management of teak nurseries and the planting of Teak seedlings in woodlots. The farmers participated in three training events, on average, for pruning, thinning and other silvicultural practices. According to $93 \%$ of the program beneficiaries, they have developed scientific knowledge and skills, and presently practice sustainable forest management activities learned through the training programs.

The Forest Department had coordinated several other training programs through the Department of Agriculture, Department of Small Industries, Samurdhi Bank, and Ruhuna Development Bank. Samurdhi Bank and Ruhuna Development Bank are two government sponsored popular rural development banks in Sri Lanka. With the inception of the program, all the beneficiaries had been trained by the village level agriculture officer on compost making, nursery management, planting and cultural practices of several agricultural crops including indigenous vegetables such as chili peppers, Finger Millet. Under the Home garden Development Component of the FWL development program organized by the Forest Department together with Agriculture Department trained them further to grow agricultural crops in non-forest lands particularly in home gardens.

The majority of program beneficiaries now grow agricultural crops in their home gardens $(67 \%)$ and other lands $(60 \%)$ successfully utilizing the knowledge and skills gained through training programs. The Department of Small Industries together with Oxfam (NGO) has trained few beneficiaries $(23 \%)$ for several months on Coir-based industry, making clay bricks and wood carvings. They are presently involving in those industries after the training and earn extra income from those industries at cottage level, utilizing their gained knowledge and skills. A few beneficiaries (13\%) are involved in small scale businesses as the result of their training as well as have received small credit from Samurdhi Bank and Ruhuna Development Bank. One (3\%) of the beneficiaries has been trained for one year on building construction and plumbing at a technical college, situated $12 \mathrm{~km}$ away from the village, and is now a leading mechanic in the village earning considerable income.

\section{Natural Capital Development of the FWL Development Program}

Development of Farmers Woodlots under the FWL Development Program: The stocks of natural capital of overexploited forest and underutilized agricultural landscapes have been restored by changing the land use pattern and management strategies under the FWL development program. The FWL development program distributed 19.5 hectares of degraded shifting cultivation land that belong to the government among 39 farmers in Nidahas Gama almost equally for establishment of Teak on 25 year lease agreement. The beneficiaries of the program received an average 0.5 hectares of land in 2002 under the condition that they share $20 \%$ of the final timber harvest with the forest department. They established the Teak cultivation with 1000 plants per hectare in 2002. Pre-commercial thinning of Teak plantations has already been done twice in 
2009 and again in April 2012 to maintain 500 trees per hectare as instructed by the Forest Department. However, the beneficiaries have earned some income even from pre-commercial thinning and maintaining almost the recommended full density of tree cover. The Teak plantations now have well-grown trees with an average over $90 \%$ survival rate even without fertilizer. The plantations will be ready fin 10 to 15 years for commercial harvesting as describe by Forest Department.

All the beneficiaries grew chili peppers, brinjole, maize, sorghum, finger millet, sesame and indigenous vegetables, mixing crops as a mix-cropping together with Teak plants during the first 5 years of the FWL development program, until 2007. The compost fertilizer applied in agricultural crops during the first 5 years provided with high fertility of soil also for the initial growth of Teak trees. Cultivation of any agricultural crop after this was not possible because of very low light and poor fertility in the litter. The beneficiaries now give more care in developing their woodlot to meet current standards.

Development of Home Gardens and Other Agricultural Lands under the FWL Development Program: Livelihood impacts of community forestry management depend on the diverse patterns of social conditions, economic opportunities, livelihood activities in addition to the forest uses specific to each area. Kahanda Modara is a traditional village of about 60 years. Villagers have two main sources of income: shifting cultivation and fishing. In addition to government land used for shifting cultivation, all villagers have their substantial extent of customary owned land with permanent titles. The FWL development program provides evidence for how implementing many activities leads to benefit for the community beyond a business-as-usual scenario. The beneficiaries of the FWL development program also own village land with the average of 1.05 hectares (minimum 0.25 and maximum $3 \mathrm{ha}$ ) that is still used mainly for agricultural purposes. "Nidahas Gama" a "Model Village" was created in 1992 distributing some government lands among 75 families with permanent titles to build their houses and maintain home gardens under "Rural Re-Awakening Movement" of the government.

The beneficiaries of the FWL development program have an average of 0.45 ha (range 0.25 to 1 ha) of land in their home gardens. Some of the lands in home gardens have been fragmented with the increase of family size. Some villagers have accumulated land by buying from their neighbours. The villagers cultivate field crops: chili, brinjole, maize, sorghum, finger millet, sesame and indigenous vegetables; fruit trees mainly lime, mango, banana as well as coconut, jack and forest trees mainly teak and mahogany as mixed cropping systems in their agricultural lands and home gardens additionally after the implementation of FWL development program. The beneficiaries who had own lands less than 2.5 ha and wish to grow trees, were given 250 teak plants each at a rate of Sri Lankan Rupees 12.50 (1 US\$ = 130 SLRs)per plant by the Forest Department as an incentive. Additional plants could be purchased at the rate of Sri Lankan Rupees 25.00 per plant.

Many non-timber forest products, mainly fuel, food, medicine, forage and fibre, are produced in agroforestry lands and home gardens as a result of FWL development program and are widely used for ritual purposes. The beneficiaries of the FWL development program apply compost and some chemical fertilizer for field crops and vegetables to increase yield under the guidance of FD. However, fruit trees are grown under highly organic conditions without application of chemicals or fertilizer. Most of the beneficiaries (67\%) obtain considerable amount of vegetables and seasonal fruits from their home gardens and other lands. All the program participants have grown trees on their land, including their home gardens, without any fertilizer. They harvest individual trees mainly for the domestic, but sometimes commercial, purposes.

\section{Physical Capital Development of the FWL Development Program}

Household Welfare Development of the FWL Development Program Beneficiaries: As part of the "Rural Re-Awakening Movement" housing scheme in 1992, all the FWL beneficiaries received a small two-bedroom brick house with tile roof from the government. Some of them recently extended or modified their houses with the improvement of their financial status from implementation of the FWL development program. Further, all the beneficiaries' houses obtained grid electricity from the Electricity Board as well as the reticulated water supply from the Water Supply and Drainage Board. It can be clearly observed that the households have become better off financially and have higher household expenditure. They presently have more assets with a high level of social capital including developed community groups, their trust and solidarity, and are better able to accumulate more physical capital. About $90 \%$ of the program beneficiaries have purchased radios as the basic source of general information and entertainment. TV also has become a basic household item for $67 \%$ of the beneficiaries. Bicycle is the common mode of domestic transport for the beneficiaries. Three-wheeler (auto-rickshaw) has become a popular mode of transport for $37 \%$ of beneficiaries. Just over a quarter have the motor cycles, and $10 \%$ have vehicles as their main transport facility. All the beneficiaries have been able to purchased basic agricultural tools which are regularly used for activities on their forest land, agricultural land and home gardens.

Widening the Sources of Energy for Cooking for the FWL Development Program Beneficiaries: All the beneficiaries of the FWL development program $(100 \%)$ presently use their own firewood collected from home gardens, other agricultural lands and woodlots, as the main source of energy for domestic cocking purpose. Some of them $33 \%$ ) had purchased fuel-wood from urban fuel-wood sellers before the implementation of the program. Almost all 
the beneficiaries (93\%) are self-sufficient in firewood now, collecting it mainly from trees grown after the FWL development program. They collect an average of $4.2 \mathrm{~kg}$ (maximum 6 and minimum $3 \mathrm{~kg}$ ) per household for domestic cocking. Home gardens provide firewood for all the beneficiaries $(100 \%)$ while $43 \%$ of the beneficiaries collect firewood from both home gardens and other agricultural lands. However only $27 \%$ beneficiaries use firewood collected from their Teak woodlots together with firewood collected from home gardens and other agricultural lands for their cooking purpose. The contribution of firewood collected from the Teak woodlots for the cooking purpose is comparatively low with an average of $22 \%$ (maximum $35 \%$ and minimum $8 \%$ ) of the total use of firewood. However, the availability of firewood collected from trees and agricultural wastes in home gardens and nearby agricultural land discourage the beneficiaries FWL development program to walk and collect firewood from distance Teak woodlots . Only $7 \%$ of the beneficiaries occasionally use LP Gas as an additional source of energy for the domestic cocking purpose.

Improvement of Infrastructure by the FWL Development Program: Generally, community forestry shifts benefit flows from individual households to the community level to ensure that they gain access to the new community-level decision-making and the resources that are managed at the community level. The FWL development program had no much responsibility of improving village level infrastructure under physical capital because the "Rural Re-Awakening Movement' had completed the basic infrastructure and social welfare facilities including roads, electricity, water supply and community centre at the village level before the commencement of the program. Further, conditions of the roads are well maintained by the local government authorities as it connects the main road and the sea-beach. There are several tourist hotels along the sea-beach that serves as a popular tourist area.

\section{Financial Capital Development of the FWL Development Program}

Increased Household Annual Income of the FWL Development Program Beneficiaries: The beneficiaries of the FWL development program have been able to maintain diversified livelihood strategies with forestry, agriculture and other livelihood systems. They are obtaining sufficient income from different rural development strategies implemented by the FWL development program, to survive and to reduce risks of their livelihood systems in the village. All the FWL development program beneficiaries (100\%) are farmers. The program selected beneficiaries from "Nidahas Gama" mainly considering their experience in successful farming to make sure their active participation in the program. Further $67 \%$ of the beneficiaries are involving in fishing industry as a part-time occupation, utilizing their spare-time efficiently. The beneficiaries spend an average of 4.5 hours (maximum 7 and minimum 2.5) per day for the activities related to their FWL, home gardens and other agricultural lands as they have been trained. The main sources of income of $27 \%$ of the beneficiaries are small industries such as fibre product manufacturing, wood carving, clay bricks making as well as construction work, plumbing, and small scale trade initiated under FWL development program. The total contribution for livelihoods by forests and trees is difficult to be quantified accurately because the amount collected varying according to seasonality, access and options. Further, those who collect forest products consume a significant proportion. All the beneficiaries of the FWL development program (100\%) feel that the real value of their household income from different sources has been drastically increased after the involvement in the program (Table 1).

Table 1. Household annual income change before and after the FWL development program

\begin{tabular}{|c|c|c|c|c|c|}
\hline Source of Income & $\begin{array}{c}\text { before and after } \\
\text { the program }\end{array}$ & Mean rank & Median Rank & Test statistics* & Probability P \\
\hline Agriculture & Before & 2.6 & 3.0 & & \\
\hline & After & 4.0 & 4.0 & 4.764 & $0.000^{* *}$ \\
\hline Forest trees & Before & 1.7 & 2.0 & & $0.000^{* *}$ \\
\hline & After & 4.2 & 4.0 & 4.835 & 0.257 \\
\hline Fishing & Before & 3.0 & 3.0 & & $0.011^{* *}$ \\
\hline Small Industries & After & 3.1 & 3.0 & 1.134 & \\
\hline & Before & 1.3 & 4.0 & & $0.034^{* *}$ \\
\hline Other sources & After & 4.3 & 4.0 & 2.558 & \\
\hline & Before & 2.4 & 2.0 & & $0.000^{* *}$ \\
\hline Total Household & After & 3.6 & 4.0 & & 2.121 \\
\hline
\end{tabular}

Ranks of the Likert Scale: 1-Very low; 2-Low; 3-Moderate; 4-High; 5-Very High

*Wilcoxon Signed Ranks Test

**Significant (2-tailed) $\mathrm{p}=0.05$ 
The FWL development program has generated endogenous growth, inducing spill overs to other activities through training and other rural development programs. The program has made significant contributions to cash incomes and products for domestic consumption. According to the beneficiaries, their total house hold income has been significantly increased $(\mathrm{z}=4.686, \mathrm{p}=0.000)$ from moderate (mean 2.7, median 3.0) to high (mean 4.1, median 4.0) after the participation in the program. Forest rehabilitation by the program improves forest quality creating an economically productive community asset. The program has direct and indirect impacts on the significant increased $(\mathrm{Z}=4.835$, $\mathrm{p}=0.000$ ) household income contribution from forest trees grown in woodlot, home gardens and other agricultural lands, from the low (mean 1.7, median 2.0) to high (mean 4.2, median 4.0). Not only do they earn income from thinning their Teak woodlots but also from the forest product such as wood, timber, poles and other forest products produced in their home gardens and agricultural lands. The FWL development program paid the beneficiaries Sri Lankan Rupees 15,000 per ha of the first year of the program as a grant to establish the Teak trees. Further they were provided with a grant of Sri Lankan Rupees. 10,000 and Sri Lankan Rupees 7,500 per ha in second and third years respectively as they had successfully maintained the woodlots. The income from forest trees particularly from wood lots will be greatly increased in 10 years when the Teak trees are ready for final harvest.

The program has increased the household income contribution of agriculture significantly $(Z=4.764, p=0.000)$ from the moderate (mean 2.6, median 3.0) to high (mean 4.0, median 4.0) rank though direct and indirect impacts. The program trained the beneficiaries on agriculture through agricultural officers and provided the beneficiaries with planting materials and encouraged them to grow agricultural crops during first 5 years of the Teak woodlot establishment. Further, they were provided with free vegetable planting materials and budded-fruit plants such as lemon, mango and avocado to be planted in home gardens and other agricultural lands under the home garden development program. Even the small industries have increased the household income contribution significantly $(Z=2.56, p=0.011)$ from very low (mean 1.3, median 1.0) to high (mean 4.3, median 4.0) rank.

The program coordinated several industries to train and encourage the beneficiaries to earn additional household income in order to keep their living standard at an economically viable level. According to most of the beneficiaries $(80 \%)$, village youth are very interested in becoming involved in small industries to earn income particularly producing wood-based products marketable with the rapidly expanding tourism industry. Urban fuel-wood sellers and woodcarvers may be in semi-urban areas, are dependent on forest resources. However the increase of household income from fishing industry was not significant changed $(\mathrm{Z}=1.134, \mathrm{p}=0.257)$ ranking moderate before (mean 3.0, median 3.0) and even after (mean 3.1, median 3.0) the program. Income earning from fishing industry has not been positively influenced by the FWL development program. All the beneficiaries $(100 \%)$ agree that their household expenditure has increased greatly with the increase of income after the commencement of the program. According to them, it is very difficult to calculate annual household expenditures under different categories due to rapid diversification of their household economy with the urbanization of the area in addition to the program.

Self-Financing of Activities and Popularizing Banking Transactions among the $F W L$ development program beneficiaries: The Forest Department through the FWL development program paid the program grants to the beneficiaries in three installments of Rs. 15,000, Rs. 10,000 and Rs. 7,000 per ha during first three years in bank cheques issued by the Bank of Ceylon. The Bank of Ceylon is one of the popular governments owned commercial bank which has widely distributed branches as well as ATM facilities. The FWL development program did not organized credit or micro credit schemes for the beneficiaries. However, all the beneficiaries $(100 \%)$ have become regular customers of the bank having savings accounts, and ATM and credit cards after becoming involved in the FWL development program. They do transactions with the bank even for their domestic activities. They are liable to borrow money also from different rural development banks under different credit schemes or even on commercial purposes. The beneficiaries however do not consider the credit societies as a requirement for the program activities. They felt that micro-credit is not a priority need for program activities and do not consider their woodlot to be kept as collateral to obtain credits from the commercial banks. Private money lenders are also a common and convenient way of borrowing credits in the village with mutual understanding and trust, under urgent requirements. Borrowing little amounts of money for the urgent domestic requirements call "Atha Maru" is also a common system among the relatives and friends.

\section{Social Capital Development of the FWL Development Program}

Management of forest and other common pool resources requires some type of collective action. Collective action can be very effective where levels of social capital are high and capacity is strong. Participation of households and individuals in local institutions, and enhanced knowledge of rights and duties involved in securing a livelihood create the benefits of social capital. Creation of 'social capital' may improve the networks and contacts necessary for the rural communities to access financial capital through borrowings.

Development of Groups and Networks of the FWL development program beneficiaries: The beneficiaries of FWL development program have several village level community welfare societies. The most active society of the Nidahas Gama is the "Maranadaara Samithiya" the society to fund and organize funerals of family members of the beneficiaries. Each member contributes their membership 
fee Rs. 50 and they meet at the temple or a residence of a member almost in every other month. The "Laymen's Society" of the village Buddhist Temple also plays a very active role in order to organize and mobilize the villagers particularly the young people and children under the guidance of Buddhist monks and elderly members, for village charity works. Further this society renders a great service to improve the human values, peace and spiritual development of the society without expecting any financial or material gain at personal level. However, almost all the beneficiaries $(93 \%)$ of this program are relatives and family friends who are living in the same village for generations and are active members of those societies.

According to $90 \%$ of the beneficiaries, they always work as one community and closely help each other when necessary. The beneficiaries as a group of Community Based Organization (CBO) of FWL development program organize meetings and activities of the program occasionally with active participation of and take firm and fare decisions collectively. They meet purposely mainly under the guidance of Forest Extension Officer or Forest Development Assistant. At the inception and after the first 3 years of the FWL development program they met very often and organized training programs, field demonstrations and distribution of planting materials for mutual benefits. They met even to receive the cheques of the grants offered by the FD after the field inspections. Presently the beneficiaries meet to organize thinning operations and some important silvicultural operations of the program, following the instruction given by the FD properly. Further forest offices call $\mathrm{CBO}$ meetings conveniently and bring important decisions for the promotion of forestry, agriculture and small industries to the FWL development program beneficiaries.

The majority of the beneficiaries are the members of "Samurdhi" societies $(70 \%)$ and "Sanasa" societies $(60 \%)$ organized by two popular rural development banks operating throughout the country. "Samurdhi" is a National Program introduced by the Government in 1994 to alleviate poverty. Samurdhi Banking Association Program branched out in rural interior villages facilitate village people to enhance their savings by providing loans. Some of the beneficiaries (33\%) had borrowed small amounts of credit as well as obtained benefits of the livelihood development program of the bank. The bank implements those programs to improve the economy of low income families toward sustainable development combining agricultural development, industry, animal husbandry and fisheries, marketing and services sectors. Sanasa Bank is a well-established co-operative bank and gained popularity for the thrift and credit cooperative societies as well as for the Hunger and Poverty Reduction Program. Few beneficiaries (23\%) had borrowed money from the Sanasa Bank which provides funding for people with low income to promote their savings as well as giving loans with low interest to purchase land and built homes. Presently, most of the beneficiaries (83\%) are not interested particularly rural development credits as they use own savings created through FWL development program.
Trust and Solidarity Development of the FWL development program beneficiaries: The beneficiaries and their family members have common experience in involving in cleaning of roads and other public places such as temple, community centre voluntarily call "Shrama Dana" (offering of free labour) for generations. They often organize community activities such as New Year celebration and other religious activities through collective actions with close cooperation.

All the beneficiaries of FWL development program (100\%) feel that the trust of the village people has been further strengthened particularly toward the community based rural development strategies during and after the implementation of the program. The decisions on FWL development program activities have been taken as common decisions with trust benefiting all the beneficiaries. Common property institutions that facilitate coordination and cooperation for mutual benefit are particularly relevant to manage commonly owned natural resources. The harvesting of vegetables grown with the planting of trees in the woodlots was done without any disputes among the beneficiaries. All the woodlot management activities for the establishment of Teak plants and agricultural crops on the lands given by the Forest Department were done as a group of all the participants $(100 \%)$. Trust and solidarity, the woodlots of each participant have been demarcated by planting only one or two other trees on their boundaries instead of making fences or other means. Further, they have gotten used to sharing labour and tasks of different activities of the FWL development program through discussions and mutual agreements. Some of the beneficiaries (17\%) have harvested their vegetables in the woodlots through a rotational basis as agreed by the other beneficiaries. Even now, they are closely sharing their knowledge, labour, as well as many physical resources in working together on program activities with mutual understanding.

Development of Social Cohesion, Inclusion and Empowerment of the FWL development program beneficiaries: Social capital in many instances insufficiently addresses power, inequality, and exclusion. Rural households increase the substitutability and convertibility of one type of capital into another. However, all the beneficiaries of the FWL development program (100\%) indicate that they have further strengthened the social cohesion among them in Nidahas Gama with the upliftment of their economy and social standards. They are enjoying kinship relations they have had for generations as well as further strengthened relationships thorough inter marriages among families within the village. The importance of social cohesion is well understood by the beneficiaries as they very often help each other in occasions such as weddings, religious functions, funerals, illnesses etc. Further the community members make courtesy visits among each other during their leisure hours of the day and discuss common issues as a common habit. The officials of the FWL development program have strategically pursued the beneficiaries to take the program activities also into those discussions. 
In order to further increase their natural capital, more needs to be invested on public social goods along the lines of local people's desires and needs. Most of the beneficiaries (90\%) of the FWL development program are highly satisfied about the contribution for livelihood development by the program. However $(10 \%)$ have some reservation due to waiting time of timber production, but are generally satisfied with the program. They are satisfied not only with the direct benefits but also with other rural development programs initiated by the program. The high expectation of large amount of money from trees of in the near future $(100 \%)$, increase of household income (87\%), improvement of food security $(83 \%)$, pleasant environment and greenery of the village $(73 \%)$ are the main tangible and intangible benefits keep the beneficiaries satisfied by the program.

Information and communication improvement for the FWL development program beneficiaries: Due to the devotion and easy access, Forest Extension Officer and the Agricultural Research and Development Officer have become regular visitors, and the most familiar and friendly government officials for all the beneficiaries $(100 \%)$ of the FWL development program. According to the beneficiaries Forest Extension Officer (100\%) and the Agricultural Research and Development Officer (87\%) are the main source of knowledge and information who often communicate with them to promote the woodlots and other rural development strategies. Forest Extension Officer visits Nidahas Gama and meets with the beneficiaries of FWL development program personally once every month to make sure those beneficiaries maintain woodlots successfully. They give instructions to the FWL development program beneficiaries on cleaning and periodical thinning of the Teak plantation. In addition, during the early stages of the program, they had regular visits at least 4 times per year for the woodlots during the initial stage of the program in order to educate and train the beneficiaries on planting of Teak plants and other important silvicultural practices. Agriculture Research and Development Officers trained the beneficiaries on production technologies, improvement of farming systems, pests and diseases as well as other management practices related to crops grown in the woodlots and other lands. In addition to the formal sources of information and communication, farmers themselves exchange their knowledge and experiences among fellow farmers. Further, radio and TV programs organized by $\mathrm{FD}$, a main partner of FWL development program have also become very important source of information particularly related to agriculture for most of the beneficiaries $(80 \%)$ of the program.

\section{Conclusions and Policy Implications}

The FWL development program in Nidahas Gama has made a major contribution to the development of livelihood of the beneficiaries. Other incorporated rural development strategies, including home-gardening and small industries, provide evidence for additionality. Training and other rural development programs of the FWL development program were able to generate endogenous growth, inducing spill-over to other activities. The beneficiaries of the FWL development program are not dependent on the program for their cash income, having adopted diverse other livelihood-based activities mostly arising from the influence of activities organized by the FWL development program.

The FWL development program has improved the human capital of the beneficiaries mainly through highly relevant training programs conducted by devoted officials. They have promoted scientific knowledge and practical skills of the beneficiaries for the success of the program. The beneficiaries have developed their natural resources of woodlots as well as in their agricultural land and home gardens. Physical capital of the beneficiaries, particularly infrastructure and welfare facilities, improve their living standard and have been substantially developed because of the financial benefits from the FWL development program. Inherited social bonds and social norms together with creation of common property institutions particularly relevant to manage the FWL development program have facilitated the coordination and cooperation of program activities for mutual benefits of the beneficiaries.

The FWL development program has successfully remedied potential vulnerability to environment and social risk on the livelihoods in Nidahas Gama. The program has increased the substitutability and convertibility of human capital into knowledgeable and skilled faming and small industries. Development of groups and networks has improved social empowerment of the beneficiaries.

As a policy implication, the government could promote more rural industries for rural development strategies based on commercial forest products for the economic development of the Nidahas Gama as well as FWL development program beneficiaries. The remarkable impacts of the program could be used as an important success story for promotion of FWL development programs locally and internationally.

\section{REFERENCES}

[1] Dongol CM, Kenneth FD, Hughe H, Bigsby R (2002) Capital Formation and Sustainable Community Forestry in Nepal. Mountain Research and Development 22(1): 70-77

[2] Brown D (1999) Principles and Practice of Forest Co-Management: Evidence from West-Central Africa. European Union Tropical Forestry Paper 2. ODI, European Commission. London and Brussels

[3] Skutsch MM (1990) Social Forestry in Integrated Rural Development Planning Sri Lanka, Field Document No. 24, FAO Regional Wood Energy Development Program in Asia GCP/RAS/131/NET Bangkok, Thailand

[4] Scoones I (1998) Sustainable Rural Livelihoods: A framework for analysis. IDS, Working Paper 72, IDS, Brighton, UK 
[5] Hamilton-Peach J, Townsley P, (no date) An IFAD Sustainable Livelihoods Framework. (http://www.ifad.org/s1 a/framework/index.htm accessed 12 May, 2015)

[6] Dev OP, Springate-Baginski O, Soussan J (2003) Impacts of Community Forestry on Livelihoods in the Middle Hills of Nepal. Journal of Forest and Livelihood 3(1) July, 2003 pp 64 77 (http://www.odi.org/resources/docs/1248.pdf accessed 22 August, 2014)

[7] Gautam AP (2009) Equity and Livelihoods in Nepal's Community Forestry. International Journal of Social Forestry (IJSF), 2(2):101-122. (http://www.ijsf.org accessed 26 July, 2014)

[8] De Groot R, Van der Perk J, Chiesura A, van Vliet A, (2003). Importance and threat as determining factors for criticality of natural capital. Ecological Economics 44 (2003) 187-204 (www.elsevier.com/locate/ecolecon)

[9] Ekins P, Simon S, Deutsch L, Folke C, De Groot R (2003). A framework for the practical application of the concepts of critical natural capital and strong sustainability. Ecological Economics 44 (2003) 165_/185 (www.elsevier.com/locate/e colecon)

[10] Carney D (1998) Implementing the sustainable livelihoods approach. In D. Carney, ed. Sustainable Rural Livelihoods: What Contribution Can We Make? UK, Department for International Development. London

[11] Ucbasaran D, Westhead P, Wright M (2008) Opportunity Identification and Pursuit: Does an Entrepreneurs Human Capital Matter? Small Business Economics (2008) 30:153173

[12] Stijns JP, (2006) Natural Resource Abundance and Human Capital Accumulation. World Development 34(6): 1060 1083 (http://www.elsevier.com/locate/worlddev)

[13] Pokharel BK, Nurse M (2004) Forests and People's
Livelihood: Benefiting the Poor from Community Forestry. Journal of Forest and Livelihood 4(1) July, 2004 19-29 (forestaction.org)

[14] Bandyopadhyay S, Shyamsundar P (2004) Fuelwood Consumption and Participation in Community Forestry in India. World Bank, Washington, DC. (https://openknowledg e.worldbank.com/handle/10986/14046 License accessed 12 November, 2014)

[15] Bray DB, Merino-Pérez L, Negreros-Castillo P, Segura-Warnholtz G, Torres-Rojo JM, Vester HFM (2003) A Community-Managed Model for Sustainable Landscapes. Conservation Biology, 17(3): 672-677

[16] Soussan J, Blaikie P, Springate-Baginski O, Chadwick M (2001) Understanding Livelihood Processes and Dynamics. Livelihood-Policy Relationship in South Asia Working Paper 1, University of Leeds, UK.

[17] Pretty J, Ward H (2001) Social Capital and the Environment. World Development Vol. 29, No. 2, pp. 209-227, 2001 (http://www.elsevier.com/locate/worlddev accessed 12 November, 2014)

[18] Warner K (2007) Forestry and sustainable livelihoods. Unasylva 226/227, Vol. 58, 2007 pp 80 87

[19] Thoms CA, (2008) Community control of resources and the challenge of improving local livelihoods: A critical examination of community forestry in Nepal Geoforum 39 (2008) 1452-1465 (http://www.elsevier.com/locate/geoforu m)

[20] Jones S, (2005) Community-Based Ecotourism: The Significance of Social Capital. Annals of Tourism Research, Vol. 32, No. 2, pp. 303-324, 2005 (www.elsevier.com/locate /atoures)

[21] Kafeero F (2011) Forests and Poverty Reduction, FAO Forest Policy Service (FOEP), Rome 